\title{
CX3CR1 expression and megakaryocytic series assessment on bone marrow biopsies in acquired aplastic anemia. Correlations with hematological parameters.
}

\section{Expresia CX3CR1 şi seria megakariocitară pe biopsia osteomedulară în anemia aplastică dobândită. Corelaţii cu parametrii hematologici.}

\author{
Cosmina Ioana Gavrilut (Tomescu) $)^{1^{*}}$, Cosmina Bondor ${ }^{2}$, Bogdan Fetica ${ }^{3}$, \\ Annamaria Fulop ${ }^{3}$, Laura Urian ${ }^{1}$, Ljubomir Petrov ${ }^{4}$ \\ 1. University of Medicine and Pharmacy "Iuliu Hatieganu” Cluj Napoca, Department of Hematology; \\ 2. University of Medicine and Pharmacy "Iuliu Hatieganu” Cluj Napoca, Department of Informatics \\ and Biostatistics; 3. Oncology Institute "Prof.Dr Ion Chiricuta" Cluj Napoca, Department of \\ Pathology; 4. Oncology Institute "Prof.Dr Ion Chiricuta” Cluj Napoca, Department of Hematology
}

\begin{abstract}
The study objective was to examine the clinical and hematological significance of receptor CX3CR1 and megakaryocytes in patients with aplastic anemia. Method. 40 patients diagnosed with aplastic anemia and 10 case-control were included in the study. Were analyzed bone-marrow biopsies regarding cellularity, the presence of megakaryocytes and immunohistochemical expression of CX3CR1,CD4, CD8, CD45RO. We divided patients according to CX3CR1 intensity and the presence of megakaryocytes in 4 groups, which were analyzed comparatively. We realized the second division of patients in 4 groups, depending on the CX3CR1 intensity and cellularity of bone-marrow biopsy. Results. Statistically significant differences between the case group and the control group were observed in terms of the percentage of CD8, CD45RO positive cells and positivity for CX3CR1. In the lot of patients with aplastic anemia, we found statistically significant differences between groups with megakaryocytes present and absent, in terms of the number of lymphocytes, platelets, hemoglobin, ESR at 1 hour, ESR at 2 hours, bone marrow cellularity. Conclusions. CX3CR1 could be involved in the pathogenesis of aplastic anemia, influencing bone marrow cellularity. Megakaryocytes influence more hematological parameters, so we suggest using thrombopoietin receptor analogues as 1st line treatment along with the immunosuppressive treatment.
\end{abstract}

Keywords: CX3CR1, megakaryocytes, aplastic anemia

\section{Rezumat}

Obiectivul studiului a fost de a examina semnificaţia clinico-hematologică a receptorului CX3CR1 şi a megakariocitelor la pacienţii cu anemie aplastică. Metoda. S-au inclus în studiu 40 de pacienţi diagnosticaţi cu anemie aplastică şi 10 cazuri martor. S-au analizat biopsiile osteo-medulare în ceea ce priveşte celularitatea,

*Corresponding author: Cosmina Ioana Gavrilut (Tomescu), University of Medicine and Pharmacy”Iuliu Hatieganu", Cluj, Romania, e-mail: Gavrilut.Ioana@umfcluj.ro. 
prezenţa megakariocitelor, cât şi expresia imunohistochimică a CX3CR1, CD4, CD8, CD45RO. Am impărţit pacienţii în funcţie de intensitatea expresiei CX3CR1 şi prezenţa megakariocitelor, în 4 grupuri, care au fost analizate comparativ. Am realizat a doua împărţire a pacienţilor tot în 4 grupuri, in funcţie de intensitatea CX3CR1 şi celularitatea biopsiei osteomedulare. Rezultate. Diferenţe semnificative statistic între lotul caz şi lotul martor au fost constatate in ceea ce priveşte procentul celulelor CD8, CD45RO pozitive, precum şi pozitivitatea pentru CX3CR1. In lotul pacienţilor cu anemie aplastică, am constatat diferenţe semnificative statistic între grupurile cu megakariocite prezente şi absente, în ceea ce priveşte numărul de limfocite, trombocite, hemoglobina, VSH la 1 h, VSH la 2 ore, celularitatea medulară. Concluzii. CX3CR1 pare a avea rol în patogeneza anemiei aplastice, influenţând celularitatea medulară. Megakariocitele influentează mai mulţi parametri hematologici, astfel incât sugerăm utilizarea analogilor de receptori de trombopoetină ca tratament de linia 1 alături de tratamentul imunosupresiv.

Cuvinte cheie: $C X 3 C R 1$, megakariocite, anemia aplastică

Received: 28 th April 2015; Accepted: 24 ${ }^{\text {th }}$ September 2015; Published: $6^{\text {th }}$ December 2015

\section{Introduction}

Aplastic anemia is a disease characterized by pancytopenia and various degrees of marrow hypoplasia. The disease pathogenesis is complex, most cases being characterized by the immune destruction of hematopoietic stem cells and of progenitors. It involves CD8 + cytotoxic T lymphocytes, CD4 + T cells, including Th1, Th2, Treg, Th17 cells, NK cells, along with the abnormal production of cytokines: interferon-gamma, alpha tumor necrosis factor, beta tumor growth factor (1).

The recruitment of $\mathrm{T}$ cells in the bone marrow requires the involvement of two classes of molecules: adhesion molecules (integrins, selectins) and leukocyte chemotactic factors (chemokines). Chemokines are structurally divided in 4 categories: C, CC, CXC and CX3C, the last category described in 1997 comprised only one member: fractalkine. CX3CR1 is the unique receptor of fractalkine cytokine (CX3CL1) and can directly mediate chemotaxis and adhesion of monocytes and T cells (2). Fractalkine interaction with its receptor mediates leukocyte recruitment in autoimmune and inflammatory processes such as asthma, rheumatoid arthritis, Crohn's disease, renal ischemia, atherosclerosis (3). Fractalkine possesses pro and anti-tumor properties and is a major mediator of central and peripheral pain $(4,5)$. The role of fractalkine and of its receptor in haematological diseases is less studied $(6,7,8,9)$.

Megakaryocytes are components of the hematoforming bone marrow of which platelets will result by cytoplasm fragmentation. Megakaryocytes come from hematopoietic stem cells through megakaryocyte progenitors and precursors. Megakaryopoiesis adjustment is achieved through several cytokines, some with stimulating role such as: interleukin -3, granulocyte-macrophage colony-stimulatind factor, c-kit ligand, FLT-3 ligand, interleukin -6, interleukin -11, thrombopoietin (which has major role) and some with inhibitor role such as beta tumor growth factor, platelet factor -4 beta, thromboglobulin, interferon- $\alpha$. The thrombopoietin receptor, called c-mpl, is found on the hematopoietic stem cell, on the megakaryocyte precursors, on the megakaryocytes.

But megakaryocytes are not just an intermediate step in platelet formation; they have an active role in maintaining stem cell homeostasis and in their recovery after aggressions (10). There is a feedback of adjustment of hematopoietic stem cells in relation to megakaryocytes. Megakaryocytes regulate the cell cycle of stem cells through the secretion of cytokines $(11,12)$. Transplanted stem cells are localized preferentially between two adult megakaryocytes. Stem 
cells have an increased capacity of proliferation in co-culture with megakaryocytes (13).

Studies on CX3CR1 involvement in aplastic anemia are only in their early beginning. T cells of patients with aplastic anemia have increased chemotactic properties; this migration of T cells can be markedly inhibited by the administration of CX3CR1 antagonists. It is unknown to what extent these chemotactic properties of CX3CR1 influence bone marrow cellularity and hematological parameters in patients with aplastic anemia.

The cellularity of bone-marrow biopsy is a criterion that occurs since the definition of aplastic anemia, and influences the severity of the disease and the treatment of choice. Megakaryocytes, through the feedback with hematopoietic stem cells, have an active role in maintaining bone marrow homeostasis. Results of the studies are controversial in terms of correlation between megakaryocytes, stem cells and the occurrence of aplastic anemia.

In this study, we aimed to evaluate the significance of CX3CR1 and megakaryocytes in aplastic anemia and their relationship with hematological parameters in diagnosis.

\section{Material and methods}

The study is retrospective and includes 40 patients diagnosed with aplastic anemia in Hematology Clinic Cluj between 2000-2014 noted as follows as case group and a control group. At presentation we evaluated: age, gender, type (idiopathic or secondary), severity, complete blood count, erythrocyte sedimentation rate (ESR), lactate dehydrogenase (LDH). In all patients bone-marrow biopsy was performed, subsequently fixed in paraffin and analyzed / reviewed.

The control group includes 10 patients investigated in the same period in Hematology Clinic Cluj for lymphoproliferative disorders without bone marrow involvement. Although the study covers a long period of time, all samples were analyzed at the same laboratory.

The diagnosis of aplastic anemia was put on the basis of bone-marrow biopsy (BMB). Exclusion criteria: inadequate bone-marrow biopsies, patients lost during follow-up.

The severity of aplastic anemia was defined by the criteria of Camitta et all, namely: severe aplastic anemia defined as: bone marrow cellularity $<25 \%$ and two of the following 3 criteria: the absolute number of reticulocytes $<60.000 /$ $\mu \mathrm{l}$, number of granulocytes $<500 / \mu \mathrm{l}$ and number of platelets $<20.000 / \mu 1$, very severe aplastic anemia defined as the number granulocytes $<200$ / $\mu \mathrm{l}$, otherwise the other conditions as in case of severe form, aplastic anemia medium severity defined as 2 of the following three conditions: number of granulocytes $<1500 / \mu$, number of platelets $<50.000 / \mu 1$, hemoglobin $<10 \mathrm{~g} / \mathrm{dl}$.

Bone-marrow biopsies from both case-control studies and patients with aplastic anemia have been taken at diagnosis before starting any treatment.

Bone marrow biopsies were fixed in $10 \%$ neutral buffered formalin for 24 hours, decalcified in ethylenediamineteraacetic acid (EDTA) disodium salt acid buffer (Osteodec) for 3 hours, conventionally embedded in paraffin and and 4 micrometer thick sections were mounted on slides.

Rabbit liquid policlonal antibody to CX3CR1 (clone ab8125 Abcam, dilution 1: 100), mouse liquid monoclonal antibodies to CD45RO (clone RTU-UCH-1 Leica dilution 1: 100), CD4 (clone NCL-L-CD4 Novocastra 368 dilution 1:40), CD8 (clone C8 / 144B DakoCytmation dilution 1: 150) were used. Bone marrow nucleated cells were evaluated for staining of membrane. CX3CR1 was evaluated using a score system that takes into account both the intensity and the percentage of positive cells. For CX3CR1staining intensity we used a two-tier scale: weak and intense. As a positive control for the stains human 
splenic tissue was used. CD45RO was evaluated both on medullary lymphocytes, and on all nucleated cells. Marrow cellularity was expressed as a percentage and megakaryocytes as present or absent (where they could not be identified based on the histopathology characteristics).

We divided the group of patients depending on the intensity of CX3CR1 and presence of megakaryocytes in 4 groups, namely: group 1: CX3CR1 intense and megakaryocytes present (5 patients), group 2: CX3CR1 intense and megakaryocytes absent (10 patients), group 3: CX3CR1 weak and megakaryocytes absent (11 patients) and group 4: CX3CR1 weak and megakaryocytes present (14 patients).

The second division of the patients on groups was made depending on the intensity of CX3CR1 and cellularity of bone-marrow biopsy, namely: group A: BMB cellularity $<15 \%$ and CX3CR1 weak, group B: BMB cellularity $<15 \%$ and $\mathrm{CX} 3 \mathrm{CR} 1$ intense, group $\mathrm{C}$ : BMB cellularity $>15 \%$ and CX3CR 1 weak, and group D: BMB cellularity $>15 \%$ and CX3CR1 intense.

This study observes the principles of the Helsinki Declaration and was approved by the local ethics committee of our institution. All participants signed a written consent.

\section{Statistical analysis}

Statistical analysis was performed with Statistica.
Data were expressed as means \pm standard deviation for normally distributed variables and medians (25th-50-75th percentile) for non-normally distributed variables. To test the normal distribution we used Kolmogorov-Smirnov or Shapiro-Wilk test. Comparison between cases and controls was performed with Student $t$ test or Mann-Whitney test. The comparison between the 4 groups was performed by Anova $t$ after transformation of variables (logarithm or replacement of aberrant cases) or Kruskal-Wallis test. Potshoc Tukey HSD method was used for all pair comparisons after Anova test. The influence of various parameters on the factors studied was analyzed using two-way Anova test. Significance was assumed at $\mathrm{p}<0.05$.

\section{Results}

Demographic, clinical and biological characteristics of the two groups in the study are described in Table I.

Statistical analysis failed to emphasize significant differences in terms of age, gender, percentage of CD4 positive cells and the intensity of CX3CR1. Statistically significant differences were found in terms of the percentage of CD8 positive cells ( $3 \%$ compared to $10 \%$ ), CD45RO positive on lymphocytes ( $3 \%$ versus $15 \%$ ), CD45RO positive on all nucleated cells $(80 \%$ versus $60 \%)$ and CX3CR1 positive cells $(65 \%$ versus $80 \%$ ).

Table I. Demographic, clinical and biological characteristics of the two study groups

\begin{tabular}{lccc}
\hline Variables & Controls $(\mathbf{n}=\mathbf{1 0})$ & Cases $(\mathbf{n}=\mathbf{4 0})$ & $\mathbf{p}$ \\
\hline${ }^{*}$ Age, $\mathrm{y}$ & $37(24-55.5)$ & $40(24.2-55.7)$ & 0.80 \\
\hline Women, $\mathrm{n}(\%)$ & $6(60)$ & $23(57.5)$ & 1.00 \\
\hline${ }^{*} \mathrm{CD} 4 \%$ & $0(0-1.0)$ & $0(0-1.0)$ & 0.76 \\
\hline${ }^{*} \mathrm{CD} 8 \%$ & $3.0(1.0-7.75)$ & $10.0(5.5-20.0)$ & 0.003 \\
\hline${ }^{*} \mathrm{CD} 45 \mathrm{RO}$ on lymphocytes \% & $3.0(1.0-10.0)$ & $15.0(10.0-28.75)$ & 0.001 \\
\hline${ }^{*} \mathrm{CD} 45$ RO total \% & $80.0(75-86)$ & $60.0(50.0-80.0)$ & 0.009 \\
\hline CX3CR1 intensity, $\mathrm{n}(\%)$ & $3(30)$ & $15(37.5)$ & 0.73 \\
\hline${ }^{*} \mathrm{CX} 3 \mathrm{CR} 1$ positivity \% & $65.0(60.0-72.5)$ & $80.0(80.0-90.0)$ & $<0.001$ \\
\hline
\end{tabular}

*For non-normal distribution, data are presented as median [lower/upper quartiles] 
In the groups of patients with aplastic anemia, median age at diagnosis was $40 \pm 2.9$ years, with a slight predominance of females: 23 women $(57.5 \%)$ and 17 men (42.5\%). At the time of diagnosis, 31 cases were idiopathic $(77.5 \%)$ and 9 secondary (22.5\%). In terms of severity, 23 cases were classified as severe aplastic anemia $(57.5 \%), 13$ cases as very severe aplastic anemia $(32.5 \%)$ and 4 cases of average aplastic anemia (10\%). CX3CR1 expression was ranked as intense in 15 cases $(37.5 \%)$ and weak in 25 cases $(62.5 \%)$ and megakaryocytes as present in 19 cases and absent in 21 cases.

The biohumoral characteristics in patients with aplastic anemia at diagnosis are presented in Table II.
Statistically significant differences in univariate analysis were observed between group 1 and group 2 in terms of the number of platelets and ESR at $1 \mathrm{~h}$, between group 1 and group 3 in terms of the number of platelets, and ESR at 1 hour and 2 hours, between group 2 and group 3 regarding the number of platelets and BMB cellularity, between group 2 and group 4 regarding the number of platelets, CD4 percentage and BMB cellularity, and between group 3 and group 4 regarding the number of platelets and hemoglobin. We were unable to showcase statistically significant differences between group 1 and group 4.

The number of platelets differs significantly between group 1 and group 2, between group 1 and group 3, between group 2 and group 3, be-

Table II. Biohumoral characteristics in patients with aplastic anemia at diagnosis

\begin{tabular}{|c|c|c|c|c|c|}
\hline & $\begin{array}{c}\text { Group } 1(n=5) \\
\text { CX3CR1 intense } \\
\text { Mgk present } \\
\end{array}$ & $\begin{array}{c}\text { Group } 2(n=10) \\
\text { Cx3CR1 intense } \\
\text { Mgk absent } \\
\end{array}$ & $\begin{array}{c}\text { Group } 3(n=11) \\
\text { Cx3CR1 weak } \\
\text { Mgk absent } \\
\end{array}$ & $\begin{array}{c}\text { Group } 4(n=14) \\
\text { CX3CR1 weak } \\
\text { Mgk present }\end{array}$ & $\mathbf{p}$ \\
\hline *Age , y & $38(24-66.5)$ & $32(24.75-52)$ & $25(20-46)$ & $52(38-67.5)$ & 0.07 \\
\hline *Granulocytes / $\mu \mathrm{l}$ & $700(225-1250)$ & $260(119-550)$ & $300(80-1100)$ & $1000(387.5-1500)$ & 0.10 \\
\hline *Lymphocytes/ $\mu 1$ & $1000(700-1700)$ & $685(187.5-1400)$ & $800(450-1300)$ & $1350(837.5-2000)$ & 0.08 \\
\hline$*$ Platelets $/ \mu \mathrm{l}$ & $\begin{array}{c}30000(20500- \\
209000) \gamma . \delta\end{array}$ & $6000(3750-10750) \eta$ & $7000(4000-20000) \theta$ & $23000(8000-60250)$ & 0.001 \\
\hline *Hemoglobin $\mathrm{g} / \mathrm{dl}$ & $5.9(5.4-7.95)$ & $7.85(5.98-8.65)$ & $5.9(4.1-7.9) \theta$ & $8.35(7.95-9.90)$ & 0.001 \\
\hline ESR mm/1 h & $20 \pm 34.51 \gamma . \delta$ & $56.5 \pm 37.02$ & $87.00 \pm 28.67$ & $56.50 \pm 35.44$ & 0.009 \\
\hline $\mathrm{ESR} \mathrm{mm} / 2 \mathrm{~h}$ & $72.4 \pm 37.86 \delta$ & $107.40 \pm 25.80$ & $121.82 \pm 18.05$ & $104.00 \pm 30.74$ & 0.02 \\
\hline$* \mathrm{LDH} \mathrm{U} / \mathrm{L}$ & $390(335-849.5)$ & $385(316.5-454.5)$ & $328(240-450)$ & $461(300.75-644)$ & 0.53 \\
\hline *Reticulocytes \%o & $16(7.5-21)$ & $10(4.75-23.25)$ & $11(2-34)$ & $14(8.75-24)$ & 0.9 \\
\hline$* \mathrm{CD} 4 \%$ & $0(0-2.5)$ & $0(0-0) \eta$ & $0(0-1)$ & $1(0.75-5)$ & 0.002 \\
\hline${ }^{*} \mathrm{CD} 8 \%$ & $20(3-20)$ & $10(1-22.5)$ & $10(10-20)$ & $10(5-20)$ & 0.5 \\
\hline $\begin{array}{l}\text { *CD45RO on } \\
\text { lymphocytes } \%\end{array}$ & $20(3-30)$ & $10(1-22.5)$ & $15(10-30)$ & $15(10-26.25)$ & 0.41 \\
\hline *CD45RO total $\%$ & $60(27.5-85)$ & $70(40-81.25)$ & $60(50-70)$ & $65(60-72.5)$ & 0.8 \\
\hline $\begin{array}{l}\text { *CX3CR1 positiv- } \\
\text { ity } \%\end{array}$ & $90(70-90)$ & $85(80-90)$ & $80.0(80.0-80.0)$ & $80(80-90)$ & 0.12 \\
\hline$* \mathrm{BMB} \%$ & $20(3-20)$ & $10(1-22.5) \zeta . \eta$ & $10(10-20)$ & $10(5-20)$ & 0.001 \\
\hline
\end{tabular}

$\mathrm{Mgk}=$ megakaryocytes, $\mathrm{ESR}=$ erythrocyte sedimentation rate, $\mathrm{LDH}=$ lactate dehydrogenase, $\mathrm{BMB}=$ bone-marrow biopsy cellularity

*For non-normal distribution, data are presented as median[lower/upper quartiles]

For normally distributed variable, data are presented as mean $\pm \mathrm{SD}$

$\gamma$-p $<0.05$ for Group 1 compare with Group 2; $\delta$-p $<0.05$ for Group 1 compare with Group 3 ; $\varepsilon$-p $<0.05$ for Group 1 compare with Group 4; $\zeta$-p $<0.05$ for Group 2 compare with Group 3; $\eta$-p $<0.05$ for Group 2 compare with Group 4; $\theta$-p $<0.05$ for Group 3 compare with Group 4. 
tween group 2 and group 4, between group 3 and group 4. ESR at 1 hour differs significantly between group 1 and group 2, between group 1 and group 3; ESR at 2 hour differs significantly between group 1 and group 3. BMB cellularity differs significantly between group 2 and group 3 , and between group 2 and group 4 . The CD4 percentage differs significantly statistically between group 2 and group 4 . Hemoglobin differs significantly between group 3 and group 4 .

Group 2 includes patients with intense CX3CR1 and absent megakaryocytes, and is characterized by the lowest values of granulocytes, lymphocytes, platelets, reticulocytes and the higher value of positive CD45RO in lymphocytes.

Since in every group we have 2 variables (CX3CR1 and megakaryocytes), we wanted to validate by bivariate analysis, to what extent the hematological parameters described above are associated to any of the two variables or both variables, or the cumulative effect of the 2 variables. (Table III)

The differences between the groups in terms of the number of lymphocytes and platelet counts are associated with the presence of megakaryocytes. The differences between the groups in terms of ESR at 1 hour, ESR at 2 hours and BMB cellularity is associated with both CX3CR1 and the presence of megakaryocytes. The difference between the groups in terms of hemoglobin is associated with the cumulative effect of CX3CR1 and megakaryocytes.
Regarding the other parameters studied, the number of granulocyte respectively, $\mathrm{LDH}$, reticulocytes, the positivity for CD4, CD8, CD45RO on lymphocytes, CD45RO on all nucleated cells, there were no statistically significant differences between the groups studied.

Lymphocyte count at diagnosis was significantly lower in patients with megakaryocytes absent compared with patients with megakaryocytes present (for gathering the assumptions for two-way Anova analysis, we replaced one case outliers in group 4 (CX3CR1 - weak and megakaryocytes absent). One-way Anova analysis showed no significant differences between groups $(p=0.08)$. But two-way Anova analysis validated an effect of megakaryocytes on lymphocytes (patients with megakaryocytes absent have a significantly lower lymphocyte count than patients with megakaryocytes present) $(p=$ 0.049).

Platelet count at diagnosis was significantly lower in patients with megakaryocytes absent compared with patients with megakaryocytes present $(\mathrm{p}<0.001)$, as expected.

Hemoglobin levels at diagnosis was significantly lower in the group of patients with CX3CR1 weak and megakaryocytes absent (cumulative effect $p=0.01$ ) (for gathering the assumptions for two-way Anova analysis we replaced one case outliers in group 4). One-way Anova analysis showed significant differences between group 3 (CX3CR1-weak and megakaryocytes

Table III. Two-way Anova analysis of megakaryocytes and CX3CR1 related to hematological parameters in patients in the study group

\begin{tabular}{lccc}
\hline & Megakaryocytes (F,p) & CX3CR1 (F, p) & Combined effect (F, p) \\
\hline Lymphocytes & $4.15,0.049$ & $0.55,0.46$ & $0.44,0.51$ \\
\hline Platelets & $22.02,<0.001$ & $1.47,0.23$ & $2.39,0.13$ \\
\hline Hemoglobin & $1.49,0.23$ & $0.87,0.36$ & $7.43,0.01$ \\
\hline ESR at 1h & $9.85,0.003$ & $6.97,0.01$ & $1.63,0.21$ \\
\hline ESR at 2 h & $7.97,0.008$ & $6.05,0.02$ & $0.84,0.37$ \\
\hline BMB & $7.41,0.01$ & $7.59,0.01$ & $0.43,0.52$ \\
\hline
\end{tabular}

$\mathrm{ESR}=$ erythrocyte sedimentation rate, $\mathrm{BMB}=$ bone marrow biopsy 
absent) and group 4 (CX3CR1 - weak and megakaryocytes present) $(p=0.01)$. Two-way Anova analysis validated an interactive effect between present / absent megakaryocytes and CX3CR1 (patients with absent megakaryocytes and weak CX3CR1 have the hemoglobin significantly lower than other groups)

Marrow cellularity was significantly lower in patients with absent megakaryocytes $(\mathrm{p}=$ 0.01 ) and in patients with intense CX3CR1 (p $=0.01$ ) (for gathering the assumptions for twoway Anova analysis we logarithmed BMB cellularity). One-way Anova analysis indicated significant differences between between group 2 (CX3CR1-intense and megakaryocytes absent) and group 3 (CX3CR1 - weak and megakaryocytes absent $)(\mathrm{p}=0.04)$ and between group 2 (CX3CR1-intense megakaryocytes absent) and group 4 (CX3CR1 -weak and megakaryocytes present) $(\mathrm{p}<0.001)$. Two-way Anova analysis validated the effect of present / absent megakaryocytes on BMB cellularity (patients with absent megakaryocytes have a significantly lower BMB cellularity than patients with megakaryocytes present $)(p=0.01)$ and CX3CR 1 effect on BMB cellularity (patients with CX3CR1 intense have a significantly lower BMB cellularity than patients with CX3CR1 weak $(\mathrm{p}=0,01)$.

We further analyzed whether our observations related to megakaryocytes are not actually due to bone-marrow cellularity, so that megakaryocytes can be observed in a greater cellularity, and other hematological parameters be improved precisely because of their higher cellularity. We considered BMB median cellularity, which is $15 \%$, and drew up 4 groups, namely group A: cases with $\mathrm{BMB}$ cellularity $<15 \%$ and CX3CR1 weak, group B: cases with BMB cellularity $<15 \%$ and $\mathrm{CX} 3 \mathrm{CR} 1$ intense, group $\mathrm{C}$ : cases with cellularity $>15 \%$ and CX3CR 1 weak, and group D: cases with cellularity $>15 \%$ and CX3CR 1 intense. These 4 groups represent an analogy to groups $1,2,3$ and 4 , where we re- placed one variable, i.e. megakaryocytes, with BMB cellularity and analyzed the same hematological parameters.

The cellularity of bone-marrow biopsy $<15 \%$ occurs in $41.6 \%$ of cases, and $>15 \%$ in $58.3 \%$ of cases. In cases with BMB cellularity $<15 \%$, there is the absence of megakaryocytes in $86.7 \%$ of cases, and in cases with BMB cellularity $>15 \%$, there is the absence of megakaryocytes in $33.3 \%$ to and their presence in $66.6 \%$.

Statistically significant differences were observed between group A and group B, between group $\mathrm{A}$ and group $\mathrm{C}$, between group $\mathrm{A}$ and group $\mathrm{D}$ in terms of age and hemoglobin, between group B and group $\mathrm{C}$ in the terms of hemoglobin. We were unable to showcase the differences between group B and group D (Table IV)

Regarding all other parameters studied, namely: the number of granulocyte, lymphocyte, platelet, ESR at 1 hour, ESR at 2 hours, LDH, reticulocytes, positivity for CD4, CD8, CD45RO on lymphocytes, CD45RO on all nucleated cells, there were no statistically significant differences between the groups studied.

Since in every group we have 2 variables (CX3CR1 and bone-marrow cellularity), we wanted to validate, through bivariate analysis, to what extent the parameters described above are associated to any of the two variables or both variables, or the cumulative effect of the 2 variables.

The differences between the groups in terms of age are associated with the cellularity of bone-marrow biopsy. The differences between the groups in terms of hemoglobin are associated with the cellularity of bone-marrow biopsy and cumulative effect of bone-marrow biopsy and CX3CR1 (Table V)

Hemoglobin levels at diagnosis was significantly lower in the group of patients with CX$3 \mathrm{CR} 1$ weak and BMB $<15 \%$ (cumulative effect $p$ $=0.012$ ). One-way Anova analysis showed sig- 
Table IV. Biohumoral characteristics in patients with aplastic anemia at diagnosis

\begin{tabular}{|c|c|c|c|c|c|}
\hline & $\begin{array}{c}\text { Group A } \\
\text { BMB }<15 \% \\
\text { CX3CR1 weak }\end{array}$ & $\begin{array}{c}\text { Group B } \\
\text { BMB }<15 \% \\
\text { CX3CR1 intense }\end{array}$ & $\begin{array}{c}\text { Group C } \\
\text { BMB }>15 \% \\
\text { CX3CR1 weak }\end{array}$ & $\begin{array}{c}\text { Group D } \\
\text { BMB }>15 \% \\
\text { CX3CR1 intense }\end{array}$ & $\mathbf{p}$ \\
\hline *Age, $\mathrm{y}$ & 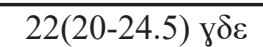 & $34.5(25.7-52)$ & $53(36.5-62.5)$ & $52(27.7-66.7)$ & 0.036 \\
\hline *Granulocytes / $\mu \mathrm{l}$ & $750(110-1500)$ & $340(187-550)$ & $1000(200-1500)$ & $395(37.5-1300)$ & 0.46 \\
\hline *Lymphocytes/ $\mu$ l & $800(575-1150)$ & $685(500-1400)$ & $1100(725-1700$ & $1200(362-1850)$ & 0.38 \\
\hline *Platelets/ $\mu \mathrm{l}$ & $4000(2000-6000)$ & $7000(4700-15000)$ & $\begin{array}{c}20000(8500- \\
54000)\end{array}$ & $\begin{array}{c}11000(8000- \\
21500)\end{array}$ & 0.14 \\
\hline *Hemoglobin $\mathrm{g} / \mathrm{dl}$ & $4.1(4-5.7) \gamma \delta \varepsilon$ & $7.1(5.7-8.1) \zeta$ & $8.4(7.4-9.8)$ & $6.8(5.6-8.7)$ & 0.049 \\
\hline ESR mm/1 h & $88 \pm 35$ & $61 \pm 33$ & $75 \pm 36$ & $72 \pm 52$ & 0.61 \\
\hline $\mathrm{ESR} \mathrm{mm} / 2 \mathrm{~h}$ & $122 \pm 23$ & $98 \pm 27$ & $108 \pm 29$ & $102 \pm 45$ & 0.52 \\
\hline$* \mathrm{LDH}$ U/L & $446(284-450)$ & $370(316-443)$ & $320(239-542)$ & $400(327-486)$ & 0.61 \\
\hline *Reticulocytes \%o & $10(4.5-41)$ & $11(4.7-23)$ & $14(4.5-22)$ & $14(3.7-23)$ & 0.62 \\
\hline$* \mathrm{CD} 4 \%$ & $0(0-1)$ & $1(0-4)$ & $0(0-3.7)$ & $0(0-2.1)$ & 0.77 \\
\hline$* \mathrm{CD} 8 \%$ & $10(8.5-20)$ & $5.5(1-12.5)$ & $10(10-20)$ & $20(8.7-27.5)$ & 0.53 \\
\hline $\begin{array}{l}\text { *CD45RO on } \\
\text { lymphocytes } \%\end{array}$ & $10(10-22.5)$ & $10(1-12.5)$ & $15(12.5-27.5)$ & $25(8.7-30)$ & 0.44 \\
\hline *CD45RO total \% & $50(30-80)$ & $80(40-86)$ & $70(60-70)$ & $42.5(21.2-71.2)$ & 0.62 \\
\hline $\begin{array}{l}\text { *CX3CR1 positiv- } \\
\text { ity } \%\end{array}$ & $80(80-85)$ & $85(80-90)$ & $80(80-80)$ & $85(65-90)$ & 0.46 \\
\hline
\end{tabular}

$\mathrm{ESR}=$ erythrocyte sedimentation rate, $\mathrm{LDH}=$ lactate dehydrogenase, $\mathrm{BMB}=$ bone-marrow biopsy cellularity

*For non-normal distribution, data are presented as median[lower/upper quartiles], For normally distributed variable, data are presented as mean \pm SD

$\gamma-\mathrm{p}<0.05$ for Group A compare with Group B; $\delta$ - $\mathrm{p}<0.05$ for Group A compare with Group C; $\varepsilon$-p $<0.05$ for Group A compare with Group D; $\zeta-\mathrm{p}<0.05$ for Group B compare with Group C

nificant differences between group A and group $\mathrm{B}$, between group $\mathrm{A}$ and group $\mathrm{C}$, between group $\mathrm{A}$ and group $\mathrm{D}$ and between group $\mathrm{B}$ and group C. Two-way Anova analysis validated an interactive effect between hemoglobin, bone-morrow biopsy and CX3CR1.

\section{Discussions}

Aplastic anemia is an autoimmune disease in which the "effectors" are T cytotoxic lymphocytes that express Th1 cytokine, especially interferon gamma (IFN $\gamma$ ). IFN $\gamma$ is produced by activated T cells and NK cells.

In this study we analyzed the T cell subpopulations of bone marrow in patients with aplastic anemia and controls and found a high percentage of CD8, CD45RO cells, which is consistent with the literature $(14,15)$. These results indicate that
T CD8 + lymphocytes accumulate in the bone marrow and cause the destruction of stem cells and of progenitors in aplastic anemia.

Next we analyzed the involvement of CX3CL1-CX3CR1 axis in the recruitment of T cells in the bone marrow of patients with aplastic anemia. CX3CL1 (fractalkine) shows an isoform bound to the cell membrane and a soluble isoform (16). Previous studies show that the expression of membrane-bound fractalkine is decreased by endothelial cells, which release soluble fractalkine as a response to Th1 cytokines, such as TNF $\alpha, \operatorname{IFN} \gamma(17,18)$. As aplastic anemia is characterized by Th1 polarization (19), the increased levels of TNF $\alpha$ and IFN $\gamma$ in the bone marrow of patients with aplastic anemia may increase the release of soluble fractalkine. CX3CR1 interaction with fractalkine facilitates the 
Table V. Two-way Anova analysis of bone marrow biopsy and CX3CR1 related to hematological parameters in patients in the study group

\begin{tabular}{lccc}
\hline & $\begin{array}{c}\text { Bone marrow biopsy } \\
<\mathbf{1 5 \%}(\mathbf{F}, \mathbf{p})\end{array}$ & CX3CR1 (F,p) & Combined effect (F, p) \\
\hline age & $7.76,0.009$ & $1.39,0.24$ & $1.81,0.18$ \\
\hline hemoglobin & $7.32,0.011$ & $0.25,0.60$ & $7.07,0.012$ \\
\hline
\end{tabular}

recruitment of $\mathrm{T}$ cells (20). Administration of antagonists for CX3CR1 and fractalkine inhibit $\mathrm{T}$ cell migration (21). Fractalkine is expressed including on CD34 positive stem cells (22).

Our results confirm an increased positivity of marrow nucleated cells for CX3CR1. CX3CR1 intensity was statistically significantly associated with bone marrow cellularity. Recently, the results of J.Ren et al. (21) validate the role of CX3CR 1 in recruitment of T cells in the bone marrow of patients with aplastic anemia. Our study, for the first time in Romania, brings information on CX3CR1 involvement in the pathogenesis of aplastic anemia.

By the cytokines they secrete, megakaryocytes actively participate in hematopoietic homeostasis, both under normal conditions and after aggression, participating in the restoration of stem cells. The absence of megakaryocytes causes a severe defect in the hematopoietic stem cell expansion (10). Administration of thrombopoietin receptor analogues determines by residual stimulating stem cells the restoration of hematopoiesis in some cases of aplastic anemia refractory to immunosuppressive agents (23).

In our study we followed the hematological parameters at diagnosis in patients with aplastic anemia, comparing the cases with present megakaryocytes and with absent megakaryocytes, and we found statistically significant differences in terms of the number of lymphocytes, platelets, hemoglobin, ESR at 1 hour, at 2 hours and marrow cellularity. We followed the same hematological parameters at diagnosis, comparing cases with bone marrow cellularity $<15 \%$ with those with bone marrow cellularity $>15 \%$, and found statistically significant differences only in terms of hemoglobin. Most cases with marrow cellularity $<15 \%$ have absent megakaryocytes.

Given the influence of megakaryocytes in all myeloid series (direct influence such that on platelets and indirect influence through the feedback with hematopoietic stem cells) and evidence that thrombopoietin receptor analogues may restore trilineage hematopoiesis in aplastic anemia, the question arises whether thrombopoietin receptor analogues would not benefit in $1^{\text {st }}$ line treatment for aplastic anemia, along with immunosuppressive treatment.

Although the group of patients is small, preliminary data seem encouraging for further evaluation. The present study aimed only the influence of CX3CR1 and megakaryocytes on the diagnosis parameters of aplastic anemia. The question is whether there is an influence on the evolution of the disease, which involves performing a longitudinal study.

\section{Conclusions}

Based on our results, we confirm previous studies, that CX3CR1 could play a role in $\mathrm{T}$ cell recruitment in aplastic anemia, thereby influencing bone marrow cellularity. Underline the importance of the correlation between megakaryocyte presence and bone-marrow restoration, in the light of some future therapies, we suggest using thrombopoietin receptor analogues in aplastic anemia since the first line of treatment, along with immunosuppressive therapy. 


\section{Acknowledgements}

This study was founded by the European Social Fund, project POSDRU/88/1.5/S/56949

\section{Conflict of interest disclosure}

None of the authors has any conflicts of interest to declare
Abbreviations
ESR-erythrocyte sedimentation rate
LDH-lactate dehydrogenase
BMB-bone marrow biopsy
IFN $\gamma$-interferon gamma
NK -natural killer cell
TNF-tumor necrosis factor
CX3CL1-fractalkine

\section{References}

1. Zeng Y, Katsanis E. The complex pathophysiology of acquired aplastic anemia. Clin Exp Immunol. 2015;180(3):361-70. DOI: 10.1111/cei.12605

2. Fong AM, Alam SM, Imai T, Haribabu B, Patel DD. CX3CR1 tyrosine sulfation enhances fractalkine-induced cell adhesion. J Biol Chem. 2002;277(22):1941823. DOI: 10.1074/jbc.M201396200

3. Kobayashi T, Okamoto S, Iwakami Y, Nakazawa A, Hisamatsu T, Chinen H, et al. Exclusive increase of CX3CR1+CD28-CD4+ T cells in inflammatory bowel disease and their recruitment as intraepithelial lymphocytes. Inflamm Bowel Dis. 2007;13(7):837-46. DOI: 10.1002/ibd.20113

4. Jamieson WL, Shimizu S, D'Ambrosio JA, Meucci O, Fatatis A. CX3CR1 is expressed by prostate epithelial cells and androgens regulate the levels of CX3CL1/ fractalkine in the bone marrow: potential role in prostate cancer bone tropism. Cancer Res. 2008;68(6):1715-22. DOI: 10.1158/0008-5472.CAN-07-1315

5. D'Haese JG, Demir IE, Friess H, Ceyhan GO. Fractalkine/CX3CR1: why a single chemokine-receptor duo bears a major and unique therapeutic potential. Expert Opin Ther Targets. 2010;14(2):207-19. DOI: $10.1517 / 14728220903540265$

6. Olsson B, Ridell B, Carlsson L, Jacobsson S, Waden- vik H. Recruitment of T cells into bone marrow of ITP patients possibly due to elevated expression of VLA4 and CX3CR1. Blood. 2008;112(4):1078-84. DOI: 10.1182/blood-2008-02-139402

7. Ferretti E, Bertolotto M, Deaglio S, Tripodo C, Ribatti D, Audrito V, et al. A novel role of the CX3CR1/ CX3CL1 system in the cross-talk between chronic lymphocytic leukemia cells and tumor microenvironment. Leukemia. 2011;25(8):1268-77. DOI: 10.1038/ leu.2011.88

8. Tsai WH, Shih CH, Feng SY, Chang SC, Lin YC, Hsu HC. Role of CX3CL1 in the chemotactic migration of all-trans retinoic acid-treated acute promyelocytic leukemic cells toward apoptotic cells. J Chin Med Assoc. 2014;77(7):367-73. DOI: 10.1016/j.jcma.2014.04.008

9. Andreasson U, Ek S, Merz H, Rosenquist R, Andersen $\mathrm{N}$, Jerkeman $\mathrm{M}$, et al. B cell lymphomas express CX3CR1 a non-B cell lineage adhesion molecule. Cancer Lett. 2008;259(2):138-45. DOI: 10.1016/j.canlet.2007.10.031

10. Zhao M, Perry JM, Marshall H, Venkatraman A, Qian $\mathrm{P}, \mathrm{He} \mathrm{XC}$, et al. Megakaryocytes maintain homeostatic quiescence and promote post-injury regeneration of hematopoietic stem cells. Nat Med. 2014;20(11):1321-6. DOI: $10.1038 / \mathrm{nm} .3706$

11. Bruns I, Lucas D, Pinho S, Ahmed J, Lambert MP, Kunisaki Y, et al. Megakaryocytes regulate hematopoietic stem cell quiescence through CXCL4 secretion. Nat Med. 2014;20(11):1315-20. DOI: 10.1038/nm.3707

12. Nakamura-Ishizu A, Takubo K, Fujioka M, Suda T. Megakaryocytes are essential for HSC quiescence through the production of thrombopoietin. Biochem Biophys Res Commun. 2014;454(2):353-7. DOI: 10.1016/j.bbrc.2014.10.095

13. Heazlewood SY, Neaves RJ, Williams B, Haylock DN, Adams TE, Nilsson SK. Megakaryocytes co-localise with hemopoietic stem cells and release cytokines that up-regulate stem cell proliferation. Stem Cell Res. 2013;11(2):782-92. DOI: 10.1016/j.scr.2013.05.007

14. Maciejewski JP, Hibbs JP, Anderson S, Katevas P, Young NS . Bone marrow and peripheral blood lymphocyte phenotype in patients with bone marrow failure. Exp Hematol 1994; 22(11): 1102-10.

15. Melenhorst JJ, Van Krieken JH, Dreef E, Landegent JE, Willemze R, Fibbe WE. T cells selectively infiltrate bone marrow areas with residual haemopoiesis of patients with acquired aplastic anaemia. Br J 
Haematol 1997; 99(3): 517-9. DOI: 10.1046/j.13652141.1997.4353245.x

16. Ostuni MA, Guellec J, Hermand P, Durand P, Combadiere $\mathrm{C}$, Pincet $\mathrm{F}$, et al. CX3CL1, a chemokine finely tuned to adhesion: critical roles of the stalk glycosylation and the membrane domain. Biol Open. 2014;3(12):117382. DOI: $10.1242 /$ bio.20149845

17. Fraticelli P, Sironi M, Bianchi G, D'Ambrosio D, Albanesi C, Stoppacciaro A, et al. Fractalkine (CX3CL1) as an amplification circuit of polarized Th1 responses. J Clin Invest 2001; 107(9): 1173-81. DOI: 10.1172/ JCI11517

18. Yoneda O, Imai T, Nishimura M, Miyaji M, Mimori $\mathrm{T}$, Okazaki T, et al. Membrane-bound form of fractalkine induces IFN-gamma production by NK cells. Eur J Immunol 2003; 33(1): 53-8. DOI: 10.1002/ immu.200390007

19. Kordasti S, Marsh J, Al-Khan S, Jiang J, Smith A, Mohamedali A, et al. Functional characterization of CD4+ $\mathrm{T}$ cells in aplastic anemia. Blood. 2012;119(9):203343. DOI: $10.1182 /$ blood-2011-08-368308
20. White GE, Greaves DR. Fractalkine: a survivor's guide: chemokines as antiapoptotic mediators. Arterioscler Thromb Vasc Biol. 2012;32(3):589-94. DOI: 10.1161/ ATVBAHA.111.237412

21. Ren J, Hou XY, Ma SH, Zhang FK, Zhen JH, Sun L, et al. Elevated expression of $\mathrm{CX} 3 \mathrm{C}$ chemokine receptor 1 mediates recruitment of $\mathrm{T}$ cells into bone marrow of patients with acquired aplastic anaemia. J Intern Med. 2014;276(5):512-24. DOI: 10.1111/joim.12218

22. Morita Y, Matsuda M, Hanamoto H, Shimada T, Tatsumi Y, Maeda Y, et al. A perforin/granzyme-positive MDS-derived $\mathrm{T}$ cell line, K2-MDS, induces apoptosis in CD34+ cells through the fractalkine-CX3CR1 system. Clin Immunol. 2004;113(1):109-16. DOI: 10.1016/j.clim.2004.05.005

23. Risitano AM. Aplastic Anemia: Alternative Immunosuppressive Treatments and Eltrombopag. A report from the 2014 EBMT Educational Meeting from the Severe Aplastic Anaemia and Infectious Diseases Working Parties. Curr Drug Targets. 2015; 14(3):20612. 
